\title{
RUSSIAN PUBLIC SECTOR ACCOUNTING: THE CASE OF EXPERIMENTAL ESTATE KONSKAYA VOLYA (1893-1905)
}

\author{
Dmitry Nazarov \\ Financial University under the Government of the Russian Federation \\ Marina Sidorova \\ Financial University under the Government of the Russian Federation
}

\begin{abstract}
For a long time, the public organizations kept the records using the cameral accounting. Then the evolution of public sector accounting methodology passed several stages in the search for new possibilities of the accounting information systems. From the $18^{\text {th }}$ century the scientists developed the idea of using the double entry bookkeeping (DEB) in the public sector accounting. A synthesis of the two systems (commercial and cameral) would enable to measure the financial position and financial results of public organization and to compare the planned and actual financial results at the same time. The high level of the theoretical studies did not match always the same quality of the accounting practice in all public institutions.

The paper describes the case of the educational unit of Novo-Alexandria Institute of Agriculture and Forestry - the experimental estate Konskaya Volya during 1893-1905 years. This case is a negative example of the practical accounting activities and does not correspond to the evolution of theoretical ideas in the public sector accounting. The authors examine the reasons for the slow dissemination of innovative methods of accounting in public institutions in Russia in the late $19^{\text {th }}$ century.
\end{abstract}

Keywords: Accounting History in Russia, Public Sector Accounting, Cameral Accounting

JEL code: M41, M48

\section{Introduction}

Recent decades have seen attempts, in various countries, to modernize public sector management and accountability. The main question of the continuous debate is how to control public money. The public sector accounting methodology is specific because the main purpose of economic subjects related to the public sector is not to make a profit but to meet the social needs. The special purposes of economic activity determine the choice of accounting objects and techniques. Therefore, the attention of researchers focuses on looking for new accounting instruments for the public sector accounting. Desired outcomes are greater financial transparency and improved basis for evaluating performance.

Traditionally, public organizations use a cameral bookkeeping method. According to Monsen $(2002,2012)$ today we find an international trend towards the introduction of commercial (full accrual or resource) accounting in the public sector. The historical development of the public sector accounting methodology demonstrates unsuccessful attempts to apply this approach in the past. It is therefore important to consider the reasons for these failures in the current transformation processes. Nowadays the research on evolution of public sector accounting methodology is not too much. The historical research in accounting were systematized in the works of Yamey (1981), Mattessich (2008), Miller et al. (1991), Carmona (2004), Napier (2006), Jacobs (2012) and others. These scientists stress the need to further research in the field of evolution of the public sector accounting methods. 
The accounting instruments evolve if the information received from accounting system does not longer meet the needs of its consumers, and if challenges facing the control system of economic entity change. To search the genealogy of accounting methods it is necessary to study the factors determining the emergence of new ideas, and consequently, the expansion of the use of different accounting techniques and procedures in practice. However, not always the appearance of innovative ideas in the accounting theory results in the immediate dissemination these ideas among all economic actors. An analysis of archival materials helps to study this issue.

The paper describes the practical accounting activities in the Russian educational unit of Novo-Alexandria Institute of Agriculture and Forestry - the experimental estate Konskaya Volya in the late $19^{\text {th }}$ century. This time was a period of significant reforms in the Russian system of public administration: the creation of local government financial bodies, the centralization of finance and the establishment of state control bodies. The order of accounting records and format of financial statements for the public sector institutions based on the principles of cameral accounting (see Medvedev and Nazarov, 2007). This period is also associated with the appearance of the original theoretical developments in the field of accounting. With regard to public sector accounting, the scientists developed various methods for the preparation of an income statement in accordance with the commercial accounting model. However, despite the active development of accounting regulation and expansion of theoretical studies the accounting practice in some Russian public sector organizations does not always correspond to the best samples. The case of Konskaya Volya estate is one of the evidence to support this thesis. The purpose of this paper is therefore first to present a new archival source and thereafter to analyze the factors that impeded the implementation of the commercial accounting as innovative method in practice of Russian public sector institutions in the late $19^{\text {th }}$ century.

\section{Public sector bookkeeping: the evolution of methodology}

The evolution of public sector accounting methods is discussed in the writings of Monsen (2002, 2012), Lambert and Lapsley (2006), Broadbent and Guthrie (2008), Gomes et al. (2008), Goddard (2010). Some papers published on Anglophone journals have devoted their attention on public sector/state accounting in different countries and societies. For example, these studies - addressed to UK (Edwards, Coombs and Greener, 2002), France (Nikitin, 2002) or Portugal-Brazil (Sangster and Rodrigues, 2013) - may be mentioned. At the same time Russian investigations - focused on the public sector accounting - are almost absent in the international literature. Sargiacomo and Gomes in their review (2011, p. 269) devotes only one article (Platonova, 2009) constituting 3.03 per cent of the publications on this topic in 11 generalist accounting journals during last fifty years. In a more recent publication, Lvova (2014) examines the relationship between different economic theories and the development of public sector accounting in Russia.

In the early stage of evolution of public sector accounting, the main purposes of management were the registration and control over the collection of revenues and expenditure. To solve this problem there was enough of the use of single-entry bookkeeping (named cameral accounting in Russia), cash based method. However, in the $16^{\text {th }}-17^{\text {th }}$ centuries the information about the inflow and outflow of cash has become insufficient to manage the finances of the state. Finance system became more complex and diversified. At that time the work of Puechberg was published, in which an attempt to form a new more advanced accounting method has been made. Enhanced by nominal accounts the accounting system did not include already realized revenues and expenditures, but also the future revenues and expenditures. Sokolov (1985, p. 122) characterized this methodology as new cameral accounting. 
On the next stage of development of public sector accounting - at the end of the $19^{\text {th }}$ century methods based on principles of cameral accounting did not solve the problem - to evaluate the assets and control the property of the state. So the idea of integration of DEB in the public sector once again drew the attention of scientists. Cerboni and Pisani created the original systems of public accounting and presented them on the World Congress of Accountants. Hügli offered the synthesis of the principles of cameral accounting and DEB (Sokolov, 1985). His innovation was to put additional accounts into the system and compute two financial results: on the one hand, comparing of the planned and actual financial results, on the other comparing of revenues and expenditures. In Russia at the beginning of $20^{\text {th }}$ century Galagan (1915) and Rudanovsky (1913) suggested own solutions of this problem. Rudanovsky was not only a scientist but also a practitioner. His theoretical ideas have been implemented in the accounting activities of the Moscow Duma (Moscow city government). However, his studies were not widely used in practice, because the introduction of this methodology resulted in an increase in the complexity of the accounting work. In addition, the theory was difficult to understand by most practitioners.

In the public sector we find different types of organizations: governmental organizations (federal and municipal) and governmental enterprises. According to Monsen (2012) the governmental organizations can however be classified as budget-linked organizations, because they primarily acquire revenues through one-way money transactions, as opposed to market-exchange transactions. Governmental enterprises receive revenues through marketexchange transactions and not through one-way money transactions so these organizations have therefore more similarities with business enterprises than with the governmental administration with regard to the acquisition of revenues for financing the expenditures incurred. Therefore, public sector organizations are not homogeneous. This fact has prompted scientists to the separation of the accounting methods recommended for use in governmental organizations and governmental enterprises. By the early 20th century the demands of the new public enterprises led to a series of reforms of cameral bookkeeping methods. The idea of using commercial accounting practices emerged again and has been modified specifically for governmental enterprises.

In summary, it can be stated that the methodology of public sector accounting was very advanced by the early 20th century, and was represented by outstanding theoretical developments.

\section{Socio-economic and methodological challenges for Russian public sector accounting in the late $19^{\text {th }}$ century}

According to Motyka, the accounting in Russia in the $16^{\text {th }}-17^{\text {th }}$ centuries may be characterized as 'rudimentary/primitive' (Motyka, 1990, p. 37). The active development of Russian public sector accounting began in the eighteenth century by means of borrowing methods of accounting practice used in Western European countries (see Galagan, 1927; Motyka, 1990; Shyroky, 1939; Sokolov, 1985). This development was driven by the administrative and economic reforms carried out by Russia's first emperor Peter the Great, who was motivated by the desire to close the gap in socio-economic development between Russia and the leading European powers. The era of Peter the Great's sole rule (1696-1725) was the time when government regulation of bookkeeping in Russia began, special accounting terminology appeared, an accountant position was introduced in government administration bodies, foreign experts knowledgeable in Western accounting techniques were invited to work for the government (Lvova, 2014; Motyka, 1990; Platonova, 2009).

Reforms in the field of state governance and the economy continued in Russia in the second half of the eighteenth century under Catherine II. During the reign of Catherine II the first 
consolidated state budget was drafted, but the control of its implementation encountered numerous problems: the lack of timeliness of reporting, inaccuracy information, the lack of verifiability. This period is associated with events that contributed to the future development of the public sector accounting in Russia: educational institutions were established where accounting was taught, translated works on double entry bookkeeping (DEB) as a more advanced method were published. Soon original Russian works in the field of public sector accounting appeared (see Arnold, 1823). Attempts to practical implementation of DEB in the public sector were undertaken only in some organizations (see Nazarov and Sidorova, 2016), because insufficient quality of the public finance system made it impossible to organize a unified accounting space.

The need to improve the accounting methodology in the public sector of Russia in the late $19^{\text {th }}$ century was determined by the increased demands of government. The quality of state financial management was insufficient. Democratic reforms and formation of the capitalist economic system, as well as the participation of Russia in the European wars were possible only under the condition of centralization of finance and tight control over all the revenues and expenditures. For this purpose, the government implemented reforms in the financial regulation: the creation of banks, the introduction of bill laws, the creation of a statistical committee, and the establishment of state control bodies (Medvedev and Nazarov, 2007). The order of accounting records and format of financial statements based on the principles of cameral accounting became obligatory for the public sector institutions and were recommended for all government agencies.

In the $19^{\text {th }}$ century the books on accounting in Russian actively published, especially texbooks. The most famous textbooks were written by such authors as Klark and Nemchinov (1831), Vavilov (1843), Kondratiev (1845), Mudrov (1846), Reynbot (1866), Prokofiev (1884) and others. Some textbooks had several editions. For example, the textbook written by A. Prokofiev The course of double-entry bookkeeping has been published 20 times until 1916. However, only $4.8 \%$ of publications among all were devoted to the public sector accounting (Sokolov, 1985, p.196). One of the notable books of this theme was the book V. N. Khitrovo Accounting in the application to the government processes (1860, St. Petersburg). This period in Russia is also associated with the appearance of the original theoretical developments in the field of accounting by Feldgauzen, Wolf, Belov, Baratz, Popov, Shmelev, Jezierski. These scientists were high-level professionals who have united around the journal Accounting (Sokolov, 1985, p. 172).

By the end of the $19^{\text {th }}$ century the first professional association of accountants in Russia was created. In the formation of the accounting profession in Russia significant changes also were made: accounting as a special discipline was included into university courses, the number of business schools increased, schools of a new type - commercial knowledge courses appeared (courses of the Society for the Propagation of commercial knowledge, Jezierski courses, Kiev higher commercial courses and others). In future commercial higher education institutions were created on the basis of some of them (Karelskaya and Zuga, 2015). In general, educational process was realized as practical training on keeping the records in the books, mostly predestinated for commercial and industrial enterprises.

\section{The experimental estate Konskaya Volya as an example of the Russian professional education institution}

This paper examines the practical accounting activities of state educational organization Novo-Alexandria Institute of Agriculture and Forestry, which is one of the first in Europe and Russia of higher agricultural education. The Institute was founded in 1816 in a suburb of Warsaw Marimonte. In 1892, by the actions of the rector Dokuchaev Institute received equal 
rights with other Russian universities. The Institute had one of the best in Russia and Europe agricultural museums, 3 laboratories, a veterinary clinic, a meteorological station, experimental farms, greenhouses, tree nurseries, a library, a reading room. One of the experimental farms was located in the estate Konskaya Volya. For many years, the students went to the farm to carry out practical research, studying the peculiarities of conducting various branches of livestock and crop production.

In November 1905, the special Commission was organized by Institute management. Its objective was to analyze the causes of unsatisfactory financial position of the experimental estate. Materials of this Commission were published (Memoirs, 1907). This source represented the description of the accounting practice of the public educational institution in the late $19^{\text {th }}$ and early $20^{\text {th }}$ century. These documents were included in the publication:

- Commission meeting protocols, which contain a description of the experimental estate economy and its financial position over the past 10 years (from 1895 to 1905) with recommendations how to resolve the crisis;

- memorandum of some members of the Commission (Kalugin, Shirokih) with their opinions of the causes of the crisis;

- reports of the directors, managed the estate in some periods (Organov, Barakov) with the analysis of financial results of the estate and their explanations;

- inventory act, dated 11 November, 1901, with the list of lands, buildings, animals, equipment and stocks.

The estate Konskaya Volya had a land with area about 650 hectares, which includes fields, meadows, orchards and forests, and a variety of buildings: the three farms (Konskaya Volya, Pojog and Gornaya Niva), a brick factory, an old building of the brewery, stables, barns, etc. There were 128 cows, 43 pigs, 349 sheep, 54 horses in experimental estate in 1901. The main types of estate revenues were the sale of plant foods (beetroot, clover, wheat) and livestock products (milk, meat, wool); sale of bricks; rarely resale animals. The current expenditures included staff salaries, purchase of seed, feed and fertilizer, agricultural equipment. Capital expenditures related to the repair and construction of farm buildings and houses for the workers, as well as the drainage of the soil. However, the main purpose of the existence of the estate was a training and practical activities of students - future agronomists.

As for financing of the estate, the main source of funding was its own revenues. The possibility of self-sufficiency was confirmed by estimates compiled annually. Surplus from the excess of revenues over expenditures transferred to Novo-Alexandria Institute. However, if necessary, the estate could receive funding from the Ministry of Education (on a return basis, with interest). In 1905 the estate was in a financially troubled conditions, revenues did not cover current expenditures. In addition, there was accumulation of overdue debt to the Ministry of Education on the loan and the payment of the debt to private suppliers 8,000 rubles. The Commission meetings protocol identified following causes of this crisis:

1) too strong dependence on the institution management in making operation decisions,

2) low level of agricultural technology,

3) lack of working capital,

4) the way of budgeting,

5) the absence of double entry bookkeeping.

As you can see, the first two causes of the crisis related to the organizational aspects of estate activities, while the remaining three - to financial. What is remarkable - two different points of view about the causes of deficiencies in the organization of the estate were given in the memoirs of the Commission. Members of the commission Kalugin and Shirokih insisted on the failure to observe the principles of scientific agriculture, wasteful and irrational style of 
management: "on a grand scale" costs, the wrong choice for the branches of agriculture, lack of timeliness of work, violation of a crop rotation, absence of the organizational plan (Memoirs, 1907, pp. 22 -30). On the contrary, director Barakov focused on irrational operational decisions based on the will of the institute management: periodic freezing brick sales, delays in decisions on the approval of the project drainage, bureaucratization of management, lack of control over financing, etc. (Memoirs, 1907, p.123). This disagreement is due to the fact that the committee members belonged to different levels of management.

\section{The case of negative experience in the public sector bookkeeping}

Regarding the estimates, there was randomness of evaluation methods and methods of budgeting. Each director used different methods of budgeting, based on their own preferences, experience and relationships with the top management of the Institute. Organov, director at 1883-1893, planned financial results in such a way that a surplus always detected when the revenues and expenditures were compared. Despite the fact that Institute later returned all this surplus to the estate to meet its urgent needs, however, this way of budgeting created a favorable impression on the results achieved by the estate. On the contrary, Barakov, director at 1894-1901, balanced revenues and expenditures fearing that the surplus of funds will be transferred to the Institute.

Methods of analysis of financial results even more differed from each other. The member of Commission Kalugin (Memoirs, 1907, p. 14) presented in his memorandum the analysis of performance as the calculation of the difference between planned and actual results (Table 1).

Table 1. Report on the financial performance in the estate Konskaya Volya for 1886-1892 (fragment). Variant 1 , in rubles

\begin{tabular}{|l|c|c|c|c|c|c|}
\hline \multirow{2}{*}{$\begin{array}{c}\text { Agricultural } \\
\text { year }\end{array}$} & \multicolumn{2}{|c|}{ Planned } & \multicolumn{2}{c|}{ Actual } & \multicolumn{2}{c|}{ Difference } \\
\cline { 2 - 7 } & Revenues & Expenditures & Revenues & Expenditures & Revenues & Expenditures \\
\hline $1886-87$ & $16,773.30$ & $11,947.50$ & $16,501.84$ & $9,361.09$ & -271.46 & $-2,586.41$ \\
\hline $1887-88$ & $14,858.93$ & $12,645.02$ & $11,947.16$ & $9,708.52$ & $-3,135.11$ & $-2,978.42$ \\
\hline $1888-89$ & $15,022.16$ & $11,267.00$ & $13,935.68$ & $8,640.70$ & $-1,086.47$ & $-2,626.64$ \\
\hline $1889-90$ & $14,248.40$ & $11,102.92$ & $11,755.76$ & $8,525.49$ & $-3,092.64$ & $-2,658.55$ \\
\hline $1890-91$ & $13,069.17$ & $10,259.78$ & $9,521.62$ & $9,205.50$ & $-3,547.55$ & $-1,054.28$ \\
\hline $1891-92$ & $10,203.78$ & $8,111,58$ & $8,601.47$ & $6,924.36$ & $-1,602.31$ & $-1,187.22$ \\
\hline
\end{tabular}

On the contrary, director Barakov in his report (Memoirs, 1907, p. 49) emphasized the excess of revenues over expenditures. The revenues were presented for each type of activity separately, but the information about expenditures was given as the total amount, without any allocation by the type of activity (Table 2).

Table 2. Report on the financial performance of the estate Konskaya Volya for 1886-1892 (fragment). Variant 2, in rubles

\begin{tabular}{|c|c|c|c|c|c|c|c|}
\hline \multirow{2}{*}{$\begin{array}{c}\text { Agricultural } \\
\text { year }\end{array}$} & \multicolumn{5}{|c|}{ Revenues } & Expenditures & $\begin{array}{c}\text { Excess of } \\
\text { revenues over } \\
\text { expenditures }\end{array}$ \\
\cline { 2 - 8 } & $\begin{array}{c}\text { Sales of } \\
\text { field } \\
\text { cropping } \\
\text { production }\end{array}$ & $\begin{array}{c}\text { Sale of sheep } \\
\text { wool and } \\
\text { defective } \\
\text { sheeps }\end{array}$ & Brick sale & $\begin{array}{c}\text { Other } \\
\text { income }\end{array}$ & Total & & \\
\hline $1886-87$ & 13,307 & 1,902 & 748 & 167 & 16,502 & 9,361 & 7,141 \\
\hline $1887-88$ & 8,594 & 1,762 & 1,263 & 210 & 11,947 & 9,709 & 2,238 \\
\hline $1888-89$ & 9,117 & 2,627 & 1,573 & 393 & 13,836 & 8,641 & 5,195 \\
\hline $1889-90$ & 7,265 & 1,762 & 2,063 & 150 & 11,756 & 8,525 & 3,231 \\
\hline $1890-91$ & 6,949 & 1,697 & 816 & 60 & 9,522 & 9,205 & 317 \\
\hline $1891-92$ & 6,857 & 207 & 1,160 & 250 & 8,601 & 6,924 & 1,677 \\
\hline
\end{tabular}


Another unresolved problem in the preparation of reports was an interpretation of the money transferred from the estate to the Institution. Firstly, part of the production was transferred to the Institute in natural form (such as bricks, hay), and we need to answer the principal question for the analysis of the financial performance - whether it was expenditure or part of the profit transferred. Secondly, director Barakov noted in his report that during the ten years prior to his management the financial results based only on the cash flows. However, he prepared his report including materials transfers: for example, in Revenues - brick sale at the market price, and in Expenditures - the cost of brick and the loss free transfer. Therefore, it is impossible to compare the results of two periods using such different types of reports.

The confusion observed in the procedures for obtaining and recording of additional financing. The loan of the Ministry of Education 30,000 rubles was received with submitting a written justification of future costs. Nevertheless, subsequent reports clearly indicated improper use of borrowed funds. At the same time, the director of the estate indicated in his report that the justification for the loan was prepared hastily, without taking into account the urgent needs of the estate, in the insufficient amount. In addition, the cash flow was irregular, and these delays, as well as the protracted approval process of the project draining soil led to the impossibility of accuracy in the use of the loan. Thus, the efficiency of the use of the loan in these conditions was not possible to evaluate.

We want to stress that among all members of the Commission only the director Barakov drew attention to the purpose of the experimental estate. The documents of the Commission contained discussion about the profitability or unprofitability of separate branches of agriculture. On this economic basis, the conclusion about the irrationality of the expansion of dairy farming was made, for example. However, in terms of the training of future agronomists sometimes negative financial result of the activity must be blocked by a real opportunity to study the processes of production in practice and further detailed analysis of the shortcomings and miscalculations. The director Barakov (Memoirs, 1907, p. 61) described examples of educational results. For example, the high level of geodesic research may be confirmed by the fact that the results were presented at the World Exhibition in Paris.

All the members of the Commission were solid in one thing - the importance of such reason as 'lack of regular bookkeeping'. Quoting from the document 'the need for double entry bookkeeping is an axiom of agricultural economy and therefore does not need evidence' (Memoirs, 1907, p. 16). Managers of the estate kept the records in the material and cash books since 1883, using cameral accounting method. However, it was insufficient for financial management, and in 1896 the question of the introduction of double entry bookkeeping was discussed, because 'there is no way to judge the profitability or unprofitability of the productive segments' (Memoirs, 1907, p. 18) without it. For 11 years, this problem was not solved. Director Barakov in 1899 designed chart of accounts, and the Agriculture Committee has approved it. Nevertheless, this project was not realized and only receipt and expense cashbooks as a cash flows budget were the sources for the measurement of the financial results and the financial position of the estate. It was not full system of new cameral accounting, because there were not the nominal result accounts in it. It was old traditional way to register the cash revenues and expenditures. Its advantages are simplicity and clarity. It is also noteworthy that the question about the quality of the accounting system has been set only when the financial situation became critical. The owners of the private enterprises have begun to worry about it much earlier. This indicates a low level of state control over the quality of accounting work in the Russian public sector at that time.

The existence and the degree of depreciation of tangible assets were not subject to registration in the estate accounting system on a regular basis. That is why two directors expressed quite 
opposite opinions on the financial state of the estate. Director Organov insisted on a brilliant state of estate in 1893, when he was a manager (Memoirs, 1907, p. 39):

'All the buildings, equipment, livestock, fields and all the property were transferred in November 1893 in good form ... consequently neither destruction nor disorder in the organization of the estate has not been mentioned'.

At the same time, director Barakov, who began to manage the estate since 1894, described the breakup of the estate at that time (Memoirs, 1907, p. 42):

'The estate Konskaya Volya at the moment of receiving it by me in autumn 1894 was like a bleak picture, it was in totally devastated conditions'.

The absence of systematic information about tangible assets in the accounting system made it impossible to evaluate the results of investments carried out in the estate over the last ten years. It is disadvantage of cameral accounting. The construction and drainage of soil were made in the estate Konskaya Volya, they were quite expensive (the reports contained significant amounts - for example, for the period 1897-1901 it was 58,558 rubles), but the result of this activity was difficult for identification (Memoirs, 1907, p. 95). Inventory act of 1901 is an example of a periodic inventory of assets, not related to the operational economic activity of the estate (Memoirs, 1907, p.127).

It should be noted that the Novo-Alexandria Institute was agricultural educational institution. Therefore, for the manager - a specialist in the problems of agriculture was necessary assistance in the organization of the accounting system. Accounting and analysis of performance in agriculture is quite specific area. The complex methodological problems need to be solved in the accounting system:

- the choice of the evaluation method for plant products, livestock, fertilizers;

- the choice of calculation method for agricultural production;

- depreciation of agricultural equipment in the conditions of the seasonal nature of the activity;

- the close relationship between the manufacturing processes (outcomes of one are the recourses for others).

It is very difficult to solve these problems in practice. The solution to these problems in a public institution is especially difficult, because it required synthesizing the principles of commercial and non-profit accounting. In the 19th century, some Russian authors published their works on accounting in agriculture: Pertsov (1838), Usov (1839), Preobragensky (1852), Shipov (1855), Psischev (1855), Pestrzhetsky (1864), and others (Medvedev and Nazarov, 2007). Nevertheless, it was not enough for the wide dissemination of knowledge on agriculture accounting. The special methodological and organizational support measures from the government were required: the opening of special schools for civil servants, the accounting researches for different sectors of the economy, quality control of accounting systems in public institutions. At the economic entity level, these issues moved to the fore: formation of an accounting policy, implementation of an internal control and standardization of some audit procedures.

\section{Conclusions and Implications}

The authors agree with F. Besta of the importance of working with archival primary sources (Besta, 1922). Not always the logic and consistency of accounting ideas coincides with the speed and breadth of the application of accounting methods in practice. Therefore, the study of primary sources can provide useful information about how widely innovative methods in a professional environment were perceived. 
Another difficult question for historical research is the approach to the characterization of the dynamics of historical development. We welcome the position Boyns and Edwards (2013), who believe that changes accumulate gradually, originate within the existing methods of accounting, and always meet with opportunistic behavior of accountants and management. The new way is accepted only when the benefits of its use exceed the costs. Dissemination of innovative accounting methods does not happen instantly. Many factors - both internal and external to the organization - influenced the speed and breadth of dissemination of innovations in the accounting system. In this situation, the study of negative examples of accounting practices also is useful.

Analysis of the archival documents demonstrates that the accounting practice in the estate Konskaya Volya has not kept pace with scientific accounting thought at that time. Examining the case of experimental estate Konskaya Volya, we can conclude that the state normative regulation is not sufficient measure to create a perfect accounting system, even for public institutions. In our opinion, the main causes for the poor state of the accounting system in the examined situation were such objective reasons: the lack of methodological supporting for different sectors of the economy, especially for agriculture and public sector, and the absence of a real state control over the quality of accounting work. These factors impeded the implementation of the double-entry bookkeeping in practice activity of Russian public sector institutions in the late $19^{\text {th }}$ century. The advantage of this method is a generation of systematic information about profit as financial result of operational activity and about entity's assets as characteristic of its financial position. The integration of commercial accounting and budgetlinked management is particularly relevant for governmental enterprises. Subjective factors are the low level of competence of Konskaya Volya managerial staff in the field of accounting, as well as the bureaucratization of financial system in Novo-Alexandria Institute.

In conclusion, the above example proves that it is not only a deep theoretical study, but also the special methodological and organizational support measures from the government were required for the implementation of innovative accounting methods in the public sector organization.

\section{References}

Arnold, K. (1823). About the state accounting system, St Peterburg: Printing house of the Medical Department of the Ministry of Internal Affairs.

Besta, F. (1922). La ragioneria (Accounting theory, 3 vols, 2nd edn.) Milan: Vallardi.

Boyns, T., Edwards, R. (2013). A History of Management Accounting: The British Experience. New York: Routledge.

Carmona, S. (2004). Accounting History Researce and its Diffusion in an International Context. Accounting History, vol. 9, no. 3, pp. 7-23.

Edwards, J., Coombs, H., Greener, H. (2002) British central government and 'the mercantile system of double entry' bookkeeping: a study of ideological conflict. Accounting, Organizations and Society, no. 27, pp. 637-658.

Galagan, A. (1915). Public sector accounting. Moscow: High School.

Jacobs, K. (2012). Sense of Social Practice: Theoretical Pluralism in Public Sector Accounting Research. Financial Accountability \& Management, vol. 28, no. 1, pp. 1-26.

Karelskaya, S., Zuga, E. (2015). Emerging of higher educational institutions in the area of accounting in Russia. Auditorskiye vedomosti, no. 2, pp. 83-96. (in Russian) 
Lvova, D. (2014). The sources of accounting theory of public sector economy. St Petersburg: S-P University.

Mattessich, R. (2008). Two Hundred Years of Accounting Research. An international survey of personalities, ideas and publications (from the beginning of the nineteenth century to the beginning of the twenty-first century). New York: Routledge.

Medvedev, M., Nazarov, D. (2007). History of accounting in Russia (1246-1996), Moscow: Buhgaltersky uchet. (in Russian)

Memoirs of Novo-Aleksandriysky Institute of Agriculture and Forestry (1907). St Petersburg: Printing house of M. Aleksandrov.

Miller, P., Hopper, T., Laughlin, R. (1991). The New Accounting History: An Introduction. Accounting, Organizations and Society, vol.16, no. 5/6, pp. 395-403.

Monsen, N. (2002). The Case for Cameral Accounting. Financial Accountability \& Management, vol. 18, issue 1, pp. 39-72.

Monsen, N. (2012). Development of administrative cameralistics: An example. International Journal of Government Financial Management, vol. XII, no.1, pp. 21-36.

Motyka, W. (1990). The Impact of Western Europe on Accounting Development in Tsarist Russia Prior to 1800. Abacus, no. 26 (1), pp. 36-62.

Napier, C. J. (2006). Accounts of change: 30 years of historical accounting research. Accounting, Organizations and Society, no. 31, pp. 445-507.

Nazarov, D., Sidorova, M. (2016). Accounting of palace economy in Russia in XVIII century. Audit, no. 8, pp. 19-24.

Nikitin, M. (2001). The birth of a modern public sector accounting system in France and Britain and the influence of Count Mollien. Accounting History, no. 6 (1), pp. 75-101.

Platonova, N. (2009). Peter the Great's government reforms and accounting practice in Russia. Accounting History, no.14, p. 437.

Rudanovsky, A. (1913). Principles of public accounting. Moscow: Publishing of students' committee of the Moscow Institute of Commerce. (in Russian)

Sangster, A. \& Rodrigues, L. (2013). The role of the state in the development of accounting in the Portuguese-Brazilian Empire, 1750-1822. Accounting History Rewiew, no. 23 (2), pp. 161-184.

Sargiacomo, M. \& Gomes, D. (2011). Accounting and accountability in local government: Contributions from accounting history research. Accounting History, no.16 (3), pp. 253-290.

Shyroky, V. (1939). Historical and economic analysis of Russian accounting in the XVIII century. PhD dissertation. Leningrad: Leningradsky Institut Sovetskoy Torgovli Imeni F. Engelsa, USSR. (in Russian)

Sokolov, Y. (1985). History of development of accounting. Moscow: Finance and Statistics. (in Russian)

Yamey, B. (1981). Some reflections on the writing of a general history of accounting. Accounting and Business Research, no. 11 (42), pp. 127-135. 